\title{
HEALTH EDUCATION ON THE PREVENTION OF HIV/AIDS WITH YOUNG MALE CRACK USERS ${ }^{1}$
}

\author{
Agnes Caroline Souza Pinto ${ }^{2}$, Maria Veraci Oliveira Queiroz ${ }^{3}$, Fabiane do Amaral Gubert ${ }^{4}$, Violante Augusta \\ Batista Braga ${ }^{5}$ Patrícia Neyva da Costa Pinheiro ${ }^{6}$
}

${ }^{1}$ Extracted from the thesis - Cultural Circle with young cocaine/crack users focused at HIV/aids prevention, presented at Programa de Pós-Graduação em Enfermagem, Universidade Federal do Ceará, (UFC), in 2013.

${ }^{2}$ Doctoral student. Programa de Pós-Graduação em Enfermagem, UFC. Nurse of Instituto Federal do Ceará. Fortaleza, Ceará, Brazil. E-mail: agnespinto@hotmail.com

${ }^{3}$ Ph.D. in Nursing. Professor, Departamento de Enfermagem, Universidade Estadual do Ceará. Fortaleza, Ceará, Brazil. E-mail: veracioq@ hotmail.com

${ }^{4}$ Ph.D. in Nursing. Professor, Departamento de Enfermagem, UFC. Fortaleza, Ceará, Brazil. E-mail: fabianegubert@hotmail.com

${ }^{5}$ Ph.D. in Nursing. Professor, Departamento de Enfermagem, UFC. Fortaleza, Ceará, Brazil. E-mail: violantebraga@superig.com.br

${ }^{6}$ Ph.D. in Nursing. Professor, Departamento de Enfermagem, UFC. Fortaleza, Ceará, Brazil. E-mail: neyva.pinheiro@yahoo.com.br

\begin{abstract}
The aim of this study was to promote, through Cultural Circles, a critical and reflective space on the prevention of HIV/AIDS among young crack users. An action research was carried out in 2012 through the Cultural Circle, with ten young crack users. The analysis and interpretation of results focused on the discussion according to the group experience. Youngsters showed incipient and inarticulate knowledge about AIDS, mainly myths, and considered themselves vulnerable to HIV/AIDS, given the exchange of straws and pipes for cocaine/crack use and loss of consciousness favoring non-use of condoms during intercourse and having multiple partners. Results contribute towards the nursing work with dialogical and participatory methodologies, such as Paulo Freire, in order to encourage critical reflection of both educator and learner towards the prevention of STD/AIDS among cocaine/crack users.
\end{abstract}

DESCRIPTORS: Nursing. Health Education. Acquired Immune Deficiency Syndrome. Young. Cocaine crack.

\section{EDUCAÇÃO EM SAÚDE NA PREVENÇÃO DO HIV/AIDS COM HOMENS JOVENS USUÁRIOS DE CRACK}

RESUMO: Objetivou-se promover, por meio dos Círculos de Cultura, espaço crítico-reflexivo acerca da prevenção do HIV/aids junto com jovens usuários de crack. Desenvolveu-se pesquisa-ação, realizada em 2012, através do Círculo de Cultura, com dez jovens usuários de crack. A análise e interpretação dos resultados privilegiaram a discussão conforme a experiência vivida pelo grupo. Os jovens demonstraram conhecimento incipiente e desarticulado sobre a aids, com predominância de mitos, e se consideravam vulneráveis ao HIV/aids, visto que o compartilhamento de canudos e cachimbos, para o uso da cocaína/crack, e a perda da consciência favoreciam o não uso do preservativo durante as relações sexuais e a multiplicidade de parceiros. Os resultados contribuem para que o enfermeiro trabalhe com metodologias dialógicas e participativas, como a de Paulo Freire, a fim de favorecer a reflexão crítica do educador e educando em prol da prevenção de DST/aids em usuários de crack.

DESCRITORES: Enfermagem. Educação em saúde. Síndrome da imunodeficiência adquirida. Adolescente. Cocaína crack

\section{EDUCACIÓN PARA LA SALUD EN LA PREVENCIÓN DEL VIH/SIDA CON HOMBRES JÓVENES CONSUMIDORES DE CRACK}

\begin{abstract}
RESUMEN: El objetivo fue promover, a través de los Círculos de Cultura, un espacio crítico y reflexivo sobre la prevención del VIH/SIDA entre jóvenes consumidores de cocaína/crack. Fue desarrollada una investigación-acción, en 2012 por medio del Círculo de Cultura, con diez jóvenes usuarios de cocaína/crack. El análisis e interpretación de los resultados favorecieron la discusión de la experiencia del grupo. Los jóvenes demostraron conocimiento sobre la SIDA de forma incipiente y desarticulado, con un predominio de los mitos, y se consideraban vulnerables a VIH/SIDA pues compartían los pitillos y pipas para usar el crack/cocaína y también por la pérdida de conciencia. Dichos factores favorecieron no utilización condón durante las relaciones sexuales con sus múltiples parejas. Los resultados contribuyen para que la enfermera trabaje con metodologías dialógicas y participativas como las de Paulo Freire, a fin de fomentar la reflexión crítica del profesor y del alumno hacia la prevención de ITS/SIDA en usuarios de crack/cocaína.
\end{abstract}

ESCRITORES: Enfermería. Educación en salud. Síndrome de Inmunodeficiencia Adquirida. Adolescente. Cocaína crack. 


\section{INTRODUCTION}

Crack use has become one of the major public health problems over the past 25 years in several countries, including Brazil. This drug emerged between 1984 and 1985, in poor and marginalized neighborhoods of Los Angles, New York and Miami. At the end of the 1980s, the first evidences of increased risk of infection with Human Immunodeficiency Virus (HIV) in crack $^{1}$ users emerged.

In Brazil, the use of crack began around the 1990's and it was restricted to the city of São Paulo. In 1994, the Unified Health System (SUS) officially inserted Harm Reduction (Redução de Danos, RD) in the country as a public health strategic policy. As an initial axis, it consisted in a set of practices directed to the prevention of AIDS and viral hepatitis to the transmission of the virus in vulnerable stigmatized groups through the exchange of contaminated needles and syringes in the use of injected drugs. ${ }^{2}$ Thus, many intravenous drug users changed their habits, sticking to crack because they consider it "safer" regarding HIV/ AIDS. ${ }^{3-4}$

A Brazilian study with crack users in 2013 revealed a prevalence of $4.97 \%$ of HIV infection amongst crack and/or similar drug users, about eight times the HIV prevalence estimated for the general Brazilian population. In addition, about $1 / 3$ of these users are concentrated in the 18 to 24 years age group and are predominantly male. ${ }^{5}$

In this scenario, it is important that prevention strategies among drug users are not restricted to the change of risky behavior related to drug use, but also to change in risky sexual behavior. The use of crack is directly associated with HIV infection and risky behaviors, such as the high number of partners, unprotected sex and the sex trade for crack or for money to buy the drug. ${ }^{6}$

In this sense, the behavioral change related to drugs and HIV/AIDS can be established by the awareness arising from the health education process. This process demands that health professionals - especially nurses for their relationship with this practice - take a closer look at these youngsters' reality, to reflect about their role as educators and to develop an environment focused on learning and on subject's autonomy. ${ }^{7}$

Therefore, the following question emerged: how can nursing develop preventive actions against
HIV / AIDS among young crack users? In this context, the nurse should offer guidance to youngsters regarding available alternatives for healthier attitudes in a broader sense.

Thus, this study aimed at promoting, through Cultural Circles, a critical-reflective space concerning HIV/ AIDS prevention along with young crack users.

\section{METHOD}

This is a descriptive and exploratory study with qualitative approach, using action research. ${ }^{8}$ Participants were ten young crack users, who attended a reference therapeutic community, in a Northeastern capital of Brazil. The inclusion criteria were used to select the subject as follows: males, users of the treatment unit for chemical dependents, reportedly having made use of crack. The young age group adopted was the one indicated by the International Labor Organization that states youngster as individuals between 15 to 24 , since the internment center is exclusive to males over 16 years. ${ }^{9}$

Information were produced from January to September 2012, through participant observation, field diary, video recording and the stages of the Cultural Circle.

The teaching approach of the Cultural Circle, by Paulo Freire replaces the idea of a "group of students" or a "classroom" by experience, which aims to rise to an education that emphasizes dialogue. The "circle" means that everyone is a team with no teacher, but an animator, who coordinates the debates, seeking the active participation of all in the educational process. ${ }^{10}$

The six Cultural Circles implemented followed the theoretical methodological steps by Paulo Freire, adapted to reach the proposed goals: discovery of prior knowledge, selection of words within the context of the young, creation of existential situations that were typical of the group and preparation of cases to help with he dialogue and to facilitate (de)construction and (re)construction of new knowledge.

Each Circle occurred in three stages: during reception, the discovery of the universal vocabulary of crack users, by using group techniques like modeling, painting, drawings, STD/AIDS game, videos, aiming at allowing the participants to speak about their expectations, knowledge and previous 
circles. Questioning was done through group techniques such as drama, parodies, texts and videos with questions that stimulate the critical reflection on reality. In the assessment, a synthesis took place of what was experienced in each circle, taking place through self-assessment, where participation, interest, motivation and group understanding of the content, as well as the facilitator performance, were assessed.

Data description and analysis consisted in the transcription of the shooting material, registering all speeches in their entirety, and noting the information in the field diary and the sequence of Cultural Circles. The group evaluated the interpretation of results, according to the researcher's experience and through the dialogue with the theoretical foundations of Paulo Freire method, considered relevant and enriching for the critical study of the popular speech. ${ }^{10}$

The study followed the ethical and legal aspects of research involving human subjects ${ }^{11}$ and was approved by the Universidade Federal do Ceará Ethical Research Committee, Protocol number 303/11. The Informed Consent Form was signed by the youngsters and their guardians. Youngsters were identified by the term user (U), followed by the order of their speech.

\section{RESULTS}

Six Cultural Circles were performed for the dialogue on HIV/AIDS, entitled: Knowing young people's experience with drugs; Youth vulnerability to HIV / AIDS as drug users; The relation between AIDS and drugs; Serious talk about prevention of
HIV/AIDS; What did we learn about AIDS?; and Synthesis of what was experienced.

The first circle aimed at learning the vocabulary universe of the participants. Generating words related to drugs and vulnerability was used. At this first meeting, the need for continued education with these young people was evident, to promote reflection on drugs and its complex relationship with several factors surrounding this issue, including HIV / AIDS.

The second circle included discussions that were raised in the previous circle, when it was identified that some of them did not recognize or did not know if they were vulnerable to HIV / AIDS for being crack users, although the majority were aware about this relationship. Then, the third circle showed the participants that all sexually active people are vulnerable to the spread of HIV/ AIDS and therefore all must prevent it; the effects of peer pressure were also shown.

During the circles, little knowledge of the group on the theme was evidenced, which led to the planning of the fourth circle with deeper issues about the disease. The fifth circle was designed to consolidate the knowledge about HIV/AIDS through recreational activities that allowed participants to socialize the knowledge learned in the previous circles. The sixth and final circle was a retrospective of all previous circles done through a painting by the youngsters.

Table 1 shows the description of the dynamics and activities of the six Cultural Circles and their relationship to the moments of reception, questioning and evaluation.

Table 1 - Association of Cultural Circles with moments of reception, questioning and evaluation, Fortaleza-CE, Brazil, 2013

\begin{tabular}{|l|l|l|c|}
\hline \multicolumn{1}{|c|}{ Cultural Circles } & \multicolumn{1}{c|}{ Reception } & \multicolumn{1}{c|}{ Questioning } & Assessment \\
\hline $\begin{array}{l}\text { First Circle: Knowing } \\
\text { young people's experi- } \\
\text { ence with drugs }\end{array}$ & $\begin{array}{l}\text { Presentation dynamics; } \\
\text { Explanation of Circles' aims. }\end{array}$ & $\begin{array}{l}\text { Construction of a panel, divided into four } \\
\text { parts: 1- A reason that prompted you to use } \\
\text { drugs; 2- Why young people use drugs?; } \\
\text { 3- What other resources could be used to } \\
\text { achieve the same objectives? 4- Creation of a } \\
\text { drawing based on the question: What were } \\
\text { the sensations/effects they felt when they } \\
\text { were using drugs? }\end{array}$ & Oral \\
& & & \\
\hline
\end{tabular}




\begin{tabular}{|c|c|c|c|}
\hline Cultural Circles & Reception & Questioning & Assessment \\
\hline $\begin{array}{l}\text { Second Circle: Youth } \\
\text { vulnerability to HIV/ } \\
\text { AIDS as drug users }\end{array}$ & $\begin{array}{l}\text { Reflections on the vulnerabil- } \\
\text { ity to HIV/ AIDS as a crack } \\
\text { user. }\end{array}$ & $\begin{array}{l}1 \text { - Video about the effects of crack in the } \\
\text { body. } \\
2 \text { - Video on what is HIV/AIDS. } \\
\text { 3- Conversation circle about the videos. } \\
4 \text { - Based on the video discussions, create a } \\
\text { role play. First situation: drug use and HIV } \\
\text { contamination; Second situation: drug use } \\
\text { and HIV non-contamination. }\end{array}$ & Writing \\
\hline $\begin{array}{l}\text { Third Circle: } \\
\text { The relation between } \\
\text { AIDS and drugs }\end{array}$ & $\begin{array}{l}\text { Signature search dynamics. } \\
\text { Technique about HIV trans- } \\
\text { missibility; } \\
\text { Ask participants to think of } \\
\text { an advice they would give to } \\
\text { a friend who is a drug user to } \\
\text { prevent him from HIV. }\end{array}$ & $\begin{array}{l}\text { 1- Modeling: making sculptures based on } \\
\text { this question: what do you know about STD/ } \\
\text { HIV/AIDS and their relationship with drugs? } \\
\text { 2-Video about AIDS. } \\
\text { 3- Game: sex, drugs and rock 'n' roll. }\end{array}$ & Oral \\
\hline $\begin{array}{l}\text { Fourth Circle: Serious } \\
\text { talk about the preven- } \\
\text { tion of HIV/ AIDS }\end{array}$ & $\begin{array}{l}\text { What do we know about } \\
\text { HIV / AIDS? } \\
1 \text { - Three groups are formed: } \\
\text { I (Forms of transmission); } \\
\text { II (AIDS can be caught); III } \\
\text { (AIDS is not caught); } \\
2 \text { - Educational video about } \\
\text { prevention, followed by } \\
\text { discussion. }\end{array}$ & $\begin{array}{l}1 \text { - Wearing the condom dynamics: focus on } \\
\text { knowing the condom and learning how to use } \\
\text { it correctly. } \\
2 \text { - Domino-style game about the knowledge } \\
\text { of the body and STD/AIDS prevention with } \\
\text { power point presentation. }\end{array}$ & Oral \\
\hline $\begin{array}{l}\text { Fifth Circle: } \\
\text { What did we learn } \\
\text { about AIDS? }\end{array}$ & $\begin{array}{l}\text { Requested participants to } \\
\text { draw or make a collage of im- } \\
\text { ages representing STD/AIDS } \\
\text { for them. }\end{array}$ & $\begin{array}{l}\text { Show the Prevention Rap video to stimulate } \\
\text { the creativity of creating a song, a poem or } \\
\text { parody on STD/AIDS prevention in drug } \\
\text { users. }\end{array}$ & Oral \\
\hline $\begin{array}{l}\text { Sixth Circle: } \\
\text { Synthesis of what was } \\
\text { experienced }\end{array}$ & $\begin{array}{l}\text { Individually, each participant } \\
\text { makes a retrospective of the } \\
\text { Circles through a painting on } \\
\text { canvas. }\end{array}$ & $\begin{array}{l}\text { - } 1 \text { - How could participants assist in the } \\
\text { continuation of this work for the prevention } \\
\text { of HIV/ AIDS? } \\
\text { - 2- What do they think are the most effec- } \\
\text { tive educational strategies for working with } \\
\text { young people in schools? }\end{array}$ & Oral \\
\hline
\end{tabular}

Table 2 presents the testimonials of crack users for each Cultural Circle experienced.

Table 2 - Description of testimonials of crack users and its relation with the reception, questioning and evaluation moments of Cultural Circles, Fortaleza-CE, Brazil, 2013

\begin{tabular}{|l|l|}
\hline \multicolumn{1}{|c|}{ Cultural Circles } & \multicolumn{1}{c|}{ Testimonials from crack users } \\
\hline $\begin{array}{l}\text { First Circle: Know- } \\
\text { ing young people's } \\
\text { experience with } \\
\text { drugs }\end{array}$ & $\begin{array}{l}\text { Reception: young people reported the importance of getting to know each other better. } \\
\text { Questioning: I started using drugs out of curiosity (U3); friends offered me at parties, then I accepted } \\
\text { (U4). U3: Friends who use it and make you use too and I had cousins who used it as well. U5 cited parents: } \\
\text { many people have parents who use it, especially the father, father drinking. U7: I used it to build up the cour- } \\
\text { age to get closer to the girls, to lose shyness; the drunk guy dances any music (U5). U5 started: to get closer } \\
\text { to the girls, we can train it before in front of the mirror; U1 added: to dance, it is important to enter the } \\
\text { dance class (U4). U4 described his drawing this way: I was here; I was at home just looking at the light } \\
\text { from lampposts, annoyed. U3 said: I was always at the beach, so when I went to the parties in the clubs, and } \\
\text { I used cocaine and ecstasy, I kept seeing waves, fish, and things flashing all the time. } \\
\text { Assessment: participants liked it and felt the need to tell what they have learned to other fellow } \\
\text { internees. }\end{array}$ \\
\hline
\end{tabular}




\begin{tabular}{|c|c|}
\hline Cultural Circles & Testimonials from crack users \\
\hline $\begin{array}{l}\text { Second Circle: Youth } \\
\text { vulnerability to } \\
\text { HIV / AIDS as drug } \\
\text { users }\end{array}$ & $\begin{array}{l}\text { Reception: I don't think there is this relationship between drugs and HIV because the drugged person is } \\
\text { aware of what is doing (U8); I think so, in the case of injecting drugs (U10); we are vulnerable because there } \\
\text { are women who prostitute themselves to use drugs, and the person who is not infected will use this woman, } \\
\text { and ends up infected too (U1). } \\
\text { Questioning: I did not know I could have had aluminum intoxication, because I smoked crack (U4); this } \\
\text { hygiene issue is serious, we don't even remember to take care (U7); we really stop wanting to eat, actually, } \\
\text { we do not feel hungry (U3). U2 was the one who reported to have had an STD: I got an STD only } \\
\text { once, which people call "esquentamento" (gonorrhea), but the doctor gave me some medicine there and an } \\
\text { injection. How do you do this HIV test? What kinds? (U5) what's the difference of HIV and AIDS? (U1); } \\
\text { the person does not die of AIDS, he dies because of opportunistic diseases (U3); now I got worried thinking } \\
\text { that the pipe I smoked crack with, if I shared, I could have caught HIV (U6). } \\
\text { Assessment: it was very nice, and it's because we don't have experience, but next one will be even better } \\
\text { (U5). It was a lot of fun, while we were learning, we were laughing a lot with the colleagues' performances } \\
\text { (U10). I loved it today, when it's the day you come, we wake up at } 5 \text { in the morning (U5). }\end{array}$ \\
\hline $\begin{array}{l}\text { Third Circle: } \\
\text { The relation between } \\
\text { AIDS and drugs }\end{array}$ & $\begin{array}{l}\text { Reception: "I felt very happy not to have signed on U3 card, I felt relieved (U7). I'm reflecting now that I } \\
\text { got infected real quick, trusted a friend and signed it, next time I will be more careful (U8). U5 started: I } \\
\text { would tell him to be careful with these prostitutes, and always get protection using condoms; U3 contin- } \\
\text { ued: I would tell him to stop using drugs. } \\
\text { Questioning: A boy and a girl who are having intercourse and then will use drugs. In the sculpture, there } \\
\text { are also a straw and a plate with powder inside, which illustrates the use of cocaine (U3). U5 modeled } \\
\text { the sexual intercourse between the couple that was surrounded by the question if they should use } \\
\text { condoms or not, which is what makes the person vulnerable to STDs. } \\
\text { Assessment: Today was very productive, and even more than that, we're the happiest internees from } 2012 \\
\text { (U5); everyone is looking forward to every encounter because we always learn something new and share the } \\
\text { same problems with the colleagues (U4). }\end{array}$ \\
\hline $\begin{array}{l}\text { Fourth Circle: } \\
\text { Serious talk about } \\
\text { prevention of HIV/ } \\
\text { AIDS }\end{array}$ & $\begin{array}{l}\text { Reception: Is anal sex more dangerous than vaginal sex? (U2) Is it true that there is the HIV virus in } \\
\text { breast milk, so the mother cannot breastfeed, not once? (U7); if the person has only one vaginal intercourse } \\
\text { with an HIV woman, does he contract it too? (U10). } \\
\text { Questioning: most young people did not know protection with condom, not even how to open } \\
\text { it, since most of the times, it was the partner who "tore" it with the mouth. During the game, a } \\
\text { female prosthesis was used to explain where the clitoris, urethra and vagina of the woman are } \\
\text { located. Participants were quite curious, especially those who had not had sexual intercourse. } \\
\text { Assessment: If anything appears on me now, especially in the genital region, I will go to the clinic because } \\
\text { most of these diseases have treatment (U5); if I know that a friend of mine has HIV, I won't be afraid of him } \\
\text { anymore, I will help him to do the treatment because I know I'm not going to get it (U6). }\end{array}$ \\
\hline $\begin{array}{l}\text { Fifth Circle: } \\
\text { What did we learn } \\
\text { about aids? }\end{array}$ & $\begin{array}{l}\text { Reception: It is an image of a "caipirinha" (cane spirit drink), which contains alcohol, then when the per- } \\
\text { son drinks it she doesn't know what to do, and ends up messing up, and then sex always comes up, and the } \\
\text { STD/AIDS are in this context; U2 explained his drawing; I glued three figures together, a couple having } \\
\text { sex, then a many little tubes with blood, which represent the HIV test that the person who has sex without } \\
\text { a condom should do, and in the third figure there are several dead bodies, that is the result of those people } \\
\text { who do not do the treatment. } \\
\text { Questioning: There were four group presentations: } \\
\text { Group 1- Parody: } \\
\text { AIDS I catch you without condoms, AIDS I get you foxy, At the party, a few drinks, practice safe sex, AIDS } \\
\text { catches you without condoms, AIDS I get you foxy [Parody of the song "Se eu te pego", authored by } \\
\text { Michel Teló]. } \\
\text { Group } 2 \text { - Rap 1: } \\
\text { My friend listen to me, STD is easy to avoid, I tell you that. } \\
\text { It's just using the condom and you will not contract } \\
\text { If you don't use it, ill is what you to get. } \\
\text { But look for treatment to faster healing in fact. } \\
\text { If you don't find it, death will find you I bet. } \\
\text { Assessment: youngsters have demonstrated confidence about the knowledge of safe sex through } \\
\text { the songs that they created and sung. }\end{array}$ \\
\hline
\end{tabular}




\begin{tabular}{|l|l|}
\hline \multicolumn{1}{|c|}{ Cultural Circles } & \multicolumn{1}{c|}{ Testimonials from crack users } \\
\hline $\begin{array}{l}\text { Sixth circle: Synthe- } \\
\text { sis of what was expe- } \\
\text { rienced }\end{array}$ & $\begin{array}{l}\text { Reception: In my painting, I put the AIDS symbol. It's a disease that I now have the confidence to talk } \\
\text { about, and to do what is right about (U7) I drew a condom, which I know everything about; the search for } \\
\text { the clinic to treat any STD, and the syringe shared among injection drug users that transmits the HIV } \\
\text { virus (U2). } \\
\text { Questioning: U5 began saying: What I learned, I'm already sharing with my colleagues in the therapeu- } \\
\text { tic community; U6 added: I already knew a few things, but I learned a lot more, and this way I'm going to } \\
\text { open their eyes about the dangers that the crack may cause by facilitating the transmission of HIV, it needs } \\
\text { to be passed on (U1). U2 initiated: beyond the information on drugs, that I find important, what is really } \\
\text { shocking is you showing the images of before and after the use of the drugs, how the person is all bones; U9: } \\
\text { we didn't have the idea that one day we would be like this. U7 complements: at school I had no guidance, } \\
\text { in fact, what they do there is offer drugs. } \\
\text { Assessment: facilitators exhibited a thank you video to the youngsters for every moment, for the } \\
\text { learning and exchange of experiences carried out, while the participants concluded that the circles } \\
\text { were very beneficial, fun and full of learning. }\end{array}$ \\
\hline
\end{tabular}

\section{DISCUSSION}

When asked about the reasons that led them to try drugs, most participants said that use happened under the influence of friends. Curiosity, parents and other family members who use drugs were also reported. Similarly, studies have shown that friendship with others who use some kind of drug increase the possibility of the youngsters using it. In addition, they stated that they tried drugs because of misinformation, curiosity, dissatisfaction with life, when one of the parents use drugs or when they discuss too much with parents. ${ }^{12-13}$

A Brazilian study with crack users pointed out the reasons which led them to use it for the first time, and more than half of the users in Brazil said that such use happened due to the curiosity they had to experience/feel the drug effect (58.28\% [IC95\%: 55.21-61.28)]. Family problems or affective losses were the main reasons for the early use of crack, reported by $29.19 \%$ of users (IC95\%: 26.67-31.84), and the pressure/influence of friends was reported by $26.73 \%$ (IC95\%: 23.94-29.72) of users. ${ }^{5}$

Regarding the sensations or effects they felt when using drugs, especially crack, the reports of youngsters of this study corroborate with specialized literature. Thus, the initial phase of euphoria, the most desired by users, was observed to have the following characteristics: increased alertness, well-being and self-confidence sensation, euphoria, and increased libido, which in this research was converted in attitudes towards girls. Psychiatric symptoms, such as delusions and hallucinations ${ }^{14}$ were the most frequently reported by youngsters.

None of them reported knowing aluminum intoxication because of the use of crack, given that when cans of soda or beer are used to smoke the stone, aluminum may detach from it and be inhaled along with the smoke. Consequently, aluminum ends up into the bloodstream and distributed throughout the body, causing brain, bones and kidneys damage. ${ }^{15}$

Concerning AIDS, similar studies worked on HIV/AIDS prevention with youngsters that belonged to religious groups and with street children. It discussed the same issues pointed out in this study: the difference between HIV and AIDS, opportunistic diseases, their transmission and prevention, the myths and taboos, diagnostic tests, the origin of this disease. These are relevant matters to the theme of HIV / AIDS, which are refined for each specific population studied. ${ }^{16-17}$

Regarding prevention of HIV, their advice to a friend who is a drug user included answers related the use of condoms in all sexual relationships and only one participant mentioned that the friend should stop using drugs. Even after the content was discussed, although not in depth, it was clear that they thought that virus transmission was sexual only.

It was noticed during the circles that only one participant mentioned the relationship between sexually transmitted diseases/AIDS and drugs. However, most spoke inarticulately, either only of STDS, or focusing on condom use, demonstrating not to know how drugs affect HIV infection. Also, the study with street children showed that, while under the influence of drugs, they reported being unable to take on responsible sexual behavior, like the young people from our study. ${ }^{17}$

A Brazilian study with crack users corroborates with the previous one and signals that most of the users were street children in the 30 days preceding the survey (39.04\% [95\% CI 34.18 -44.14]), which 
is an aggravating, sometimes decisive, factor concerning the risk of contracting transmissible infectious diseases. Most of the users who had vaginal sex during the 30 days prior to interview did not use a condom in at least one of these intercourses $(64,15 \%$ [IC95\% 60,71-67,45]). Inconsistent use of condom, when having oral and anal sex, was also fairly high with proportions of 79.05\% (IC95\% 75.63-82.10) and $62.00 \%$ (IC95\% 57.38-66.41), respectively, of non-use of condom in any of these sexual relationships. ${ }^{5}$

Among educational strategies used in this study, the role-play was the best and funniest way to learn, according to the evaluation done by users. The challenge to plan and present them was quite motivating and, at the same time, marked by several difficulties, regarding the resourcefulness of staging the plays, including the puppets. The youngsters requested educational videos, since the image caused greater impact on their minds than just words and it helped in memorization, which was slightly impaired due to crack use. In a study developed with street boys, they also performed the role-play as a way of learning to talk about risky behavior and safe behavior on STD/HIV/AIDS. ${ }^{17}$

Educational games were also used in this study. The domino-style game was one of them, from Projeto aids: educação e prevenção (AIDS Project: education and prevention). It was also used by another author, in his study with teenagers, which confirms this as a strategy of health education towards prevention of STD/HIV/AIDS in helping the educational phenomenon, through a combination of information, debate, reflection, mutual influence and group participation. ${ }^{18}$

It is clear that approaching HIV/AIDS issues with young people is very complex, mainly because it is an issue that involves their intimacy. However, dynamic and ludic devices relating to their reality were used, so that they could feel comfortable and participate spontaneously, without fear or shame of colleagues. In the end, everyone built knowledge collectively.

In face of those creative and reflective actions, the moment has come to start active subject participation research, using nursing pedagogical strategies to strengthen it, as well as the implementation of guidelines for human well-being through different techniques and methods.

Educational action with dance and/or music as mediator when addressing issues of interest for youngsters; such as sexuality, puberty, and STD/
HIV / AIDS prevention allowed them to rediscover the perception of risk and vulnerability in which they were in. ${ }^{19}$

Thus, teaching and learning cannot take place away from demand, away from beauty and joy. The educational practice includes all of that: affection, joy, scientific capacity, technical domain in service of change, or, unfortunately, because of today's permanence..$^{20}$ Education that enhances care should be incorporated into the practice of nursing, striving for better quality of life.

\section{FINAL CONSIDERATIONS}

Young people in the study demonstrated incipient and inarticulate knowledge with myths about the prevention of STD/AIDS. They also reported never using injected drugs; however, they acknowledged that they still consider themselves vulnerable to STD/AIDS, since sharing of straws and pipes to use cocaine and crack, respectively, and the loss of consciousness or judgment may have favored the non-use of condoms during sex and having multiple partners. These youngsters' friends were the main influencers on their decision to try drugs.

On each Circle, the use of several recreational activities such as painting, role-play, modeling, games and domino used, as well as the videos displayed, enabled the process of "decision-making" provided by critical thinking development, favoring a broader view of the reality in which they are inserted. The nurse, by using creative and active dynamics throughout the teaching-learning process, enabled reflections on the search for solutions for problematic situations experienced interactively.

The study contributes towards scientific knowledge and nursing practice, as no previous work addressed the intervention with drug users in an inclusive manner, using strategies integrating various activities, including ludic ones. With the exploration of the drug theme, it was noticed that most researches are carried out by doctors and psychiatrists and are of quantitative nature. Regarding nurses, most studies discussed the knowledge of nursing students on drugs and how nursing education prepares students for this topic.

In this research, the real situation of risk and vulnerability in which these young men found them were identified. In addition, it showed several health education activities carried out with them, and 
for them, which facilitated the awareness process concerning STD/AIDS within this specific population. With the help of the participants, an educational proposal was designed to be used with other youngsters or children who are in school and who have not yet had contact with drugs, i.e. preventive work, created with people who are already on the other side of the process, in treatment stages, but recognize the seriousness of the problem.

It is important to note the limitations of this study, namely: the young people did not have reflective practice in its continuous treatment process, often wanting to remain passively; and the lack of continuity of educational activities in order to monitor subject's transformation process.

It is necessary that nurses, as promoters of youth health, approach their reality through discussions on topics that are not often recognized by young people as important, in order to build adequate autonomy towards the promotion of health.

\section{REFERENCES}

1. Azevedo RCS, Moraes MJ. HIV/aids e doenças sexualmente transmissíveis entre usuários de crack. In: Ribeiro M, Laranjeira R. O tratamento do usuário de crack. $2^{\mathrm{a}}$ ed. Porto Alegre (RS): Artmed; 2012. p. 57-73.

2. Niel M, Silveira DX. Drogas e redução de danos: uma cartilha para profissionais de saúde. São Paulo: Ministério da Saúde; 2008.

3. Perrenoud L, Ribeiro M. Histórico do consumo de crack no Brasil e no mundo. In: Ribeiro M, Laranjeira R. O tratamento do usuário de crack. $2^{\mathrm{a}}$ ed. Porto Alegre (RS): Artmed; 2012. p. 34-8.

4. Nappo AS, Sanchez Z, Oliveira LGD. Crack, AIDS, and Women in Sao Paulo, Brazil. Substance Use Misuse [Internet]. 2011 [cited 2013 Jul 25]; 46(4):476-85. Available from: http:/ / www.tandfonline.com/doi/ full/10.3109/10826084.2010.503480\#preview

5. Bastos FI, Bertoni N. Pesquisa nacional sobre o uso de crack: quem são os usuários de crack e/ ou similares do Brasil? Quantos são nas capitais brasileiras? [Internet] Rio de Janeiro: Icict/Fiocruz; 2014 [cited 2015 Apr 12]. p. 71-7. Available from: https://www.icict.fiocruz. $\mathrm{br} /$ sites/www.icict.fiocruz.br/files/Pesquisa \% 20 Nacional\%20sobre\%20o\%20Uso\%20de\%20Crack.pdf

6. Strathdee SA, Stockman JK. Epidemiology of HIV among injecting and non-injecting drug users: current trends and implications for interventions. Curr HIV/ AIDS Rep [Internet]. 2010 [cited 2012 Jul 18]; 7(2):99106. Available from: http:/ / www.ncbi.nlm.nih.gov/ pmc/articles/PMC2856849/

7. Bastable SB. Panorama da educação em saúde no cuidado em saúde. In: Bastable SB. O enfermeiro como educador. $3^{\text {a }}$ ed. Porto Alegre (RS): Artmed;
2010. p. 25-45.

8. Thiollent M. Metodologia da pesquisa-ação. $18^{\mathrm{a}}$ ed. São Paulo: Cortez; 2011.

9. Organização Internacional do Trabalho (OIT). Trabajo decente y Juventude en América: avance febrero 2010. Oficina Regional para América Latina y el Caribe [Internet]. OIT; 2010. [cited 2012 Apr 15]. Available from: http://www.oit.org.mx/pdf/noticias/TDJ $\% 20$ Avance\%20con\%20anexos.pdf

10. Brandão CR. O que é método Paulo Freire. $32^{\mathrm{a}}$ ed. São Paulo: Brasiliense; 2011.

11. Brasil. Conselho Nacional de Saúde. Resolução 466/12. Diário Oficial União, 2013 jun [cited 2012 Jun 10].12, Seção 1, p. 59. Available from: http:/ / conselho. saude.gov.br/resolucoes/2012/Reso466.pdf

12. Facundo FRG, Pedrão LJ, García KLG, Castillo MMA, Almanza SEE. El consumo de drogas como una práctica cultural dentro de las pandillas. Rev LatinoAm Enfermagem [Internet]. 2011 [cited 2012 Apr 28]; 19(Spe): Available from: http://dx.doi.org/10.1590/ S0104-11692011000700023

13. Silva K L, Dias FLA,Vieira NFC, Pinheiro PNC. Reflexões acerca do abuso de drogas e da violência na adolescência. Esc Anna Nery [Internet]. 2010 [cited 2011 Out 13]; 14(3):605-10. Available from: http:/ / www.scielo.br/scielo.php?pid=S1414$81452010000300024 \&$ script $=$ sci_arttext

14. Ribeiro M, Nudelman ED, Rezende EP, Yamauchi R. Farmacologia do consumo de crack. In: Ribeiro M, Laranjeira R. O tratamento do usuário de crack. $2^{\mathrm{a}}$ ed. Porto Alegre (RS): Artmed; 2012.p. 116-42.

15. Oliveira LG, Nappo AS. Characterization of the crack cocaine culture in the city of São Paulo: a controlled pattern of use. Rev Saúde Pública [Internet]. 2008 [cited 2011 Nov 12]; 42(4):664-71.. Available from: http://www.scielo.br/scielo.php?script=sci arttext\&pid=S0034-89102008000400012

16. Ferreira AGN, Vieira NFC, TransferettiJA, GalvãoMTG, Gubert FA, Pinheiro PNC. Talking with adolescents from religious groups about HIV: challenges for nursing. Texto Contexto Enferm [Internet]. 2013 [cited 2014 Jan 23]; 22(4):952-60. Available from: http://www.scielo.br/scielo.php?script=sci arttext\&pid=S0104-07072013000400011

17. Luna IT, Costa AGM, Costa MS, Alves MDS, Vieira NFC, Pinheiro PNC. Conhecimento e prevenção das doenças sexualmente transmissíveis entre os adolescentes em situação de rua. Ciênc Cuid Saúde [Internet]. 2013 [cited 2014 Feb 13]; 12(1):346-55. Available from: http://www.periodicos.uem.br/ ojs/index.php/CiencCuidSaude/article/view/18693

18. Barbosa SM, Dias FLA, Pinheiro AKB, Pinheiro PNC, Vieira NFC. Jogo educativo como estratégia de educação em saúde para adolescentes na prevenção às DSTs. Rev Eletr Enferm [Internet]. 2010 [cited 2012 Mar 24]; 12(2):337-41. Available from: http:/ / dx.doi. org/10.5216/ree.v12i2.6710 
19. Costa AGM, Vieira NFC. Estratégia de promoção da saúde pela dança (EPSD) com adolescentes. Rev Bras Educ Física, Esporte, Lazer Dança. 2009; 4(2):62-74.
20. Freire P. Pedagogia da autonomia: saberes necessários à prática educativa. São Paulo: Paz e Terra; 2011. 